Original Research Paper

\title{
Blood Biochemical Profiles and Pregnancy Rate of Brahman Crossbred Cows Supplemented with Mineral Mixture
}

\author{
Mohammad Sofi'ul Anam, Ali Agus, Lies Mira Yusiati, Chusnul Hanim, \\ Andriyani Astuti, Sigit Bintara and Muhsin Al Anas \\ Faculty of Animal Science, Universitas Gadjah Mada, Yogyakarta, Indonesia
}

\author{
Article history \\ Received: 14-06-2021 \\ Revised: 04-08-2021 \\ Accepted: 08-08-2021 \\ Corresponding Author: \\ Mohammad Sofi'ul Anam \\ Faculty of Animal Science, \\ Universitas Gadjah Mada \\ Yogyakarta, Indonesia \\ Email: m.sofiul.a@mail.ugm.ac.id
}

\begin{abstract}
The investigation was expected to assess various mineral mixture supplementation impacts on Brahman crossbred cows' blood biochemical, hematological profiles and pregnancy rate. This study used ninety Brahman crossbred cows divided into three dietary treatment groups ( $n=30$ /group). The dietary treatments were: Concentrate and rice straw only as control treatment; control diet + mineral mixture A-formulation as MM-A treatment; and control diet + mineral mixture B-formulation as MM-B treatment. The concentration of MM-B (including calcium, phosphor, cobalt, copper, sulphur, potassium, zinc, manganese, magnesium, sodium, selenium and iron) was higher than MM-A. The mineral mixture was added to $0.5 \mathrm{~kg} / 100 \mathrm{~kg}$ of diet. The concentrate mix and rice straw were restricted to $3 \mathrm{~kg}$ and $20 \mathrm{~kg} / \mathrm{day}$ (as-fed basis). Feeding treatment was conducted until four months. Blood sampling and estrous synchronization were carried out after three weeks of dietary treatments. The estrous synchronization aimed to equate the estrous cycle of each cow by using $25 \mathrm{mg}$ prostaglandin $\mathrm{F} 2 \alpha$ (Lutalyse $^{\mathrm{TM}}$ ) (injection via intramuscular). Estrous signs were observed two days after synchronization. Artificial insemination was conducted at ten to twelve hours from estrous detection, inseminated with post-thawed frozen Belgian Blue bull sperm. Transrectal palpation was used to diagnose the cow's pregnancy 90 days after artificial insemination. The serum samples were analyzed for blood biochemical, hematology and mineral status. The results showed that MM-B supplementation significantly increased $(\mathrm{p}<0.05)$ serum calcium, phosphor, selenium and iron. There were no significant differences in serum glucose, total protein, albumin, cholesterol, triglyceride, creatinine, uric acid, blood urea nitrogen and hematological profile. The pregnancy rate in MM-B treatment was higher than MM-A and control treatment. The pregnancy rate in the MM-B treatment (20.7\%) was higher than control (6.67\%) and MM-A treatment (3.33\%). It was concluded that mineral mixture supplementation improved the pregnancy rate and several blood components on Brahman Crossbred cows.
\end{abstract}

Keywords: Supplementation, Mineral Mixture, Blood Biochemical, Pregnancy Rate, Brahman Crossbred Cows

\section{Introduction}

The increasing meat consumption in Indonesia is in line with the increasing human population every year. However, there is still an imbalance between the supply and demand of meat. Most cattle production comes from smallholder farms, in which reproductive cattle tend to lack minerals, resulting in the low reproductive performance of animals (Agus and Widi, 2018; Khalil et al., 2019a). Minerals, both macro and trace minerals, play an essential function in regulating the reproduction and production of animals. Productive livestock most often suffers from nutritional inadequacies because of high production and lack of feed. So, this condition leads to poor reproductive performance in animals (Talukdar et al., 2016). The presence of minerals deficiency on feed can cause reproduction problems in animals. Reproduction problems occurred were reported by many researchers, including hypocalcaemia, abortion of a foetus, retained placenta, vaginal prolapse, dystocia, inconsistent estrous and decreasing on reproductive performance of cows (Ahuja and Parmar, 2017; Caixeta et al., 2017; Kumar et al., 2011; 
Mokolopi, 2019; Yatoo et al., 2018). Mineral supplementation can also increase pregnancy percentage on repeat breeder animals (Ahmed et al., 2010).

Niaz et al. (2017) stated that supplementation of minerals in the diet significantly increased serum mineral content, resulting in improved reproductive performance of animals. Many researchers have conducted studies of single mineral components on cows' reproduction, including oral calcium supplementation increased the pregnancy rates (Martinez et al., 2016). When phosphor intakes are low, it decreases ovarian activity, irregular oestrous cycles, delayed onset of puberty and low conception rates (Bindari et al., 2013). Supplementation of copper, zinc, manganese increased the pregnancy rate in beef cattle (Ahola et al., 2004), increasing calf mortality may be caused by deficiency of cobalt concentration in the diet (Patterson et al., 2003). Selenium provided to cows at some stage in the pre-and postpartum intervals results in the early recuperation of luteal function and an improved conception rate (Kamada, 2017).

However, not many studies have reported the effect of a mixture of various minerals, both macro and micro, on reproductive performance in beef cows through artificial insemination methods. This research was conducted to evaluate the effects of different mineral mixture components on Brahman crossbred cows' blood chemical profiles and pregnancy rate.

\section{Materials and Methods}

\section{Ethical Approval}

Certificated number 00021/EC-FKH/Eks./2021 approved the experimental procedure, Faculty of Veterinary Medicine, Universitas Gadjah Mada.

\section{Location of Study}

The experimental study was conducted at the PT. Widodo Makmur Perkasa, located at Cikalongkulon, Cianjur district, West Java, Indonesia.

\section{Animal and Design}

Ninety Brahman Crossbreed cows (mean Body Weight (BW), 394 $\pm 62.04 \mathrm{~kg}$, aged 3-4 years, had at least calved once) were randomly assigned to three pens. Each pen had 30 cows as replication. The Brahman Crossbred cows were fed according to the dietary treatments. This study had three treatments based on the diets: Concentrate mix and rice straw only as $\mathrm{CON}$ treatment, control diet + mineral mixture A-formulation as MM-A treatment and control diet + mineral mixture B-formulation as MM-B treatment. The mineral mixture was formulated with different ratios of mineral content. The mineral content of MM-B was made higher than MM-A (Table 1). The mineral mixture was added to $0.5 \mathrm{~kg} / 100 \mathrm{~kg}$ of diet. The concentrate mix and rice straw were restricted to $3 \mathrm{~kg}$ and $20 \mathrm{~kg} /$ day (as-fed basis). The chemical composition of the feed has been presented in Table 2. Animal always had ad libitum water. The dietary treatments were carried out until pregnancy diagnosis (four months).

\section{Estrous Synchronization}

In the third-week feeding treatments, estrous synchronization was carried on each treatment group ( $\mathrm{n}=30 /$ group $)$. Before it, transrectal palpation was conducted to confirm the existence and condition of an active corpus luteum. The estrous synchronization aimed to equate the estrous cycle of each cow by using $25 \mathrm{mg}$ prostaglandin F2 $\alpha$ (Lutalyse ${ }^{\mathrm{TM}}$, Dinoprost-T, Zoetis Inc.) (injection via intramuscular). Estrous signs were noticed two days after synchronization based on vulva condition (redness, swelling, warmth), mucus discharge from the vagina, cows' anxiety, or standing to be mounted by other cows (Susilowati et al., 2021).

\section{Artificial Insemination and Pregnancy Diagnosis of Brahman Crossbred Cows}

The estrous cows were inseminated with post-thawed frozen Belgian Blue bull sperm. The frozen Belgian Blue sperm was imported from Belgian Blue Group (BBG Scrl, Ciney, Belgium). The frozen sperm was thawed using sterile water $\left(37^{\circ} \mathrm{C}\right)$ for $30 \mathrm{sec}$, then was used to inseminate the 30-Brahman crossbred recipients of each treatment. The Artificial Insemination (AI) was carried out from ten until twelve hours after the estrous detection. The 21-day non-return to estrus (Saili, 2017) was used for early pregnancy detection. Pregnancies were confirmed through transrectal palpation at 90 days post-AI (Leigh et al., 2019).

Table 1: Mineral component of mineral mixture

\begin{tabular}{lrr}
\hline Component & \multicolumn{1}{c}{ MM-A } & \multicolumn{1}{c}{ MM-B } \\
\hline Calcium $(\mathrm{mg} / 100 \mathrm{~g})$ & 27806.18 & 21117.02 \\
Phosphor $(\mathrm{mg} / \mathrm{kg})$ & 7419.61 & 58101.81 \\
Sodium $(\mathrm{mg} / 100 \mathrm{~g})$ & 2840.24 & 7244.98 \\
Sulfur $(\mathrm{mg} / \mathrm{kg})$ & 2093.19 & 6540.32 \\
Manganese $(\mathrm{mg} / \mathrm{kg})$ & 817.40 & 2133.73 \\
Magnesium $(\mathrm{mg} / 100 \mathrm{~g})$ & 305.12 & 699.50 \\
Zinc $(\mathrm{mg} / 100 \mathrm{~g})$ & 36.61 & 171.94 \\
Copper $(\mathrm{mg} / \mathrm{kg})$ & 49.23 & 547.30 \\
Potassium $(\mathrm{mg} / 100 \mathrm{~g})$ & 20.56 & 274.49 \\
Iron $(\mathrm{mg} / 100 \mathrm{~g})$ & 962.06 & 1379.15 \\
Cobalt $(\mathrm{mg} / \mathrm{kg})$ & 3.79 & 4.65 \\
Selenium $(\mathrm{mcg} / 100 \mathrm{~g})$ & 6.35 & 33.86 \\
\hline
\end{tabular}

Table 2: Chemical composition of feeds fed to Brahman crossbred cows (\%, DM basis)

\begin{tabular}{lcc}
\hline Item & Concentrate & Rice straw \\
\hline Dry matter & 88.79 & 61.76 \\
Crude protein & 13.04 & 5.25 \\
Ether extract & 3.18 & 0.75 \\
Crude fiber & 21.68 & 28.36 \\
Crude ash & 8.43 & 23.35 \\
Nitrogen-Free Extract (NFE) & 53.67 & 39.79 \\
Total Digestible Nutrient (TDN) & 46.34 & 45.21 \\
\hline
\end{tabular}


The number of pregnant cows divided with inseminated animals in each group was used to calculate the pregnancy rate.

\section{Dietary and Blood Collection-Analysis}

The amount of feed given (rice straw and concentrate) was recorded every day. The dietary samples were collected every 3-weeks during the research period. Chemical composition, including Dry Matter (DM), Organic Matter $(\mathrm{OM})$, Crude Protein (CP), Crude Fibre (CF) and Extract Ether (EE), was determined according to the method reported by AOAC (2005). Blood samples from all cows in each treatment group were taken in the morning before feeding. To determining blood biochemical and mineral profiles, we used blood serum. The amount of $10 \mathrm{~mL}$ of blood samples was taken from the caudal vein of Brahman Crossbred cows using the BD vacutainer ${ }^{\circledR}$ blood collection needle. The blood samples were directly transferred to 10-mL BD vacutanier® serum tubes. The blood samples were left for $15 \mathrm{~min}$ then were centrifuged at $2000 \mathrm{rpm}$ for $20 \mathrm{~min}$. The serums that had been separated from the blood cells were then taken and subjected to further testing. Serum biochemical and macromineral were analyzed by DiaSys Diagnostic System, Holzheim, Germany, using commercially available kits: Glucose, total protein, albumin, cholesterol, triglyceride, creatinine, uric acid, Blood Urea Nitrogen (BUN), calcium and phosphor. The selenium and iron serum concentration were determined utilizing the Atomic Absorption Spectrophotometer (AAS).

For the blood hematology analysis, $3 \mathrm{~mL}$ of whole blood was transferred into a $3 \mathrm{~mL} \mathrm{K3}$ EDTA blood collection tube (Valucab®, OneMed, Surabaya). Samples were directly refrigerated at $\sim 4^{\circ} \mathrm{C}$ within $24 \mathrm{~h}$ of blood collection for hematology analysis. The hematological parameters included: Hemoglobin concentration, hematocrit, total erythrocyte count, total leucocyte count, Mean Corpuscular Volume (MCV), Mean Corpuscular Hemoglobin (MCH), Red cell Distribution Width (RDW), total count and percentage of granulocyte, lymphocyte and monocyte. Progesterone hormone analysis was determined by ELISA kit (DRG Progesterone EIA-1561, DRG International, Inc., USA) and estrogen hormone analysis was determined by ELISA kit (DRG estradiol EIA-2693, DRG International, Inc., USA).

\section{Statistical Analysis}

All data were analyzed of variance in SAS University Edition® Software (www.sas.com). The mean differences were tested using Duncan Multiple Range Test at the significant $\mathrm{p}<0.05$.

\section{Results}

This study showed that mineral mixture supplementation had no significant differences ( $p>0.05$ ) in biochemical blood profiles (glucose, total protein, albumin, cholesterol, triglyceride, creatinine, uric acid, BUN) among different groups (Table 4). Likewise, mineral mixture supplementation did not significantly differ with blood hematology from the hemoglobin concentration, hematocrit, erythrocyte count, leukocyte count, MCV, $\mathrm{MCH}, \mathrm{RDW}$, granulocyte count, granulocyte percentage and lymphocyte percentage (Table 5).

Table 3: Feed intake of Brahman crossbred cows supplemented with mineral mixture (kg DM/head/day)

\begin{tabular}{lrrr}
\hline Nutrient ntake & CON & MM-A & MM-B \\
\hline Dry matter & 17.43 & 17.51 & 17.44 \\
Organic matter & 13.76 & 13.82 & 13.78 \\
Crude protein & 1.10 & 1.08 & 1.16 \\
Ether extract & 0.20 & 0.19 & 0.20 \\
Crude fiber & 4.83 & 4.78 & 4.72 \\
Nitrogen-Free Extract (NFE) & 7.26 & 7.37 & 7.33 \\
Total Digestible Nutrient (TDN) & 7.75 & 7.77 & 7.81 \\
\hline
\end{tabular}

Table 4: Serum biochemical and mineral profile on Brahman crossbred cows supplemented with mineral mixture

\begin{tabular}{|c|c|c|c|c|}
\hline Item & $\mathrm{CON}$ & MM-A & MM-B & $p$-value \\
\hline \multicolumn{5}{|l|}{ Biochemistry } \\
\hline Glucose $\left(\mathrm{mg} \mathrm{dl}^{-1}\right)$ & $54.47 \pm 7.53$ & $70.57 \pm 8.20$ & $66.77 \pm 1.69$ & 0.220 \\
\hline Protein $\left(\mathrm{g} \mathrm{dl}^{-1}\right)$ & $7.26 \pm 0.56$ & $8.18 \pm 0.26$ & $9.07 \pm 0.62$ & 0.068 \\
\hline Albumin $\left(\mathrm{g} \mathrm{dl}^{-1}\right)$ & $4.21 \pm 0.48$ & $4.04 \pm 0.22$ & $3.76 \pm 0.17$ & 0.602 \\
\hline Cholesterol (mg dl $\left.{ }^{-1}\right)$ & $289.18 \pm 11.51$ & $296.28 \pm 21.70$ & $303.75 \pm 21.41$ & 0.862 \\
\hline Trygliceride $\left(\mathrm{mg} \mathrm{dl}^{-1}\right)$ & $37.17 \pm 7.38$ & $41.97 \pm 7.67$ & $58.32 \pm 13.02$ & 0.300 \\
\hline Creatinine $\left(\mathrm{mg} \mathrm{dl}^{-1}\right)$ & $2.35 \pm 0.65$ & $2.43 \pm 0.21$ & $2.55 \pm 0.21$ & 0.946 \\
\hline Uric acid $\left(\mathrm{mg} \mathrm{dl}^{-1}\right)$ & $3.11 \pm 0.94$ & $4.49 \pm 0.94$ & $3.63 \pm 0.92$ & 0.448 \\
\hline $\mathrm{BUN}\left(\mathrm{mg} \mathrm{dl}^{-1}\right)$ & $15.35 \pm 0.78$ & $15.13 \pm 0.59$ & $16.16 \pm 0.81$ & 0.590 \\
\hline \multicolumn{5}{|l|}{ Mineral } \\
\hline Calcium (mg dl $\left.{ }^{-1}\right)$ & $9.83 \pm 0.17^{\mathrm{a}}$ & $10.69 \pm 0.29^{\mathrm{ab}}$ & $11.60 \pm 0.42^{\mathrm{b}}$ & 0.004 \\
\hline Phosphor (mg dl $\left.{ }^{-1}\right)$ & $2.79 \pm 0.14^{\mathrm{a}}$ & $3.80 \pm 0.33^{\mathrm{b}}$ & $3.97 \pm 0.34^{\mathrm{b}}$ & 0.220 \\
\hline Selenium $(\mathrm{mcg} / 100 \mathrm{~mL})$ & $6.62 \pm 0.81^{\mathrm{a}}$ & $8.05 \pm 0.40^{\mathrm{ab}}$ & $9.97 \pm 1.03^{b}$ & 0.029 \\
\hline $\operatorname{Iron}(\mathrm{mg} / 100 \mathrm{~mL})$ & $1.27 \pm 0.41^{\mathrm{a}}$ & $2.68 \pm 0.61^{\mathrm{ab}}$ & $3.51 \pm 0.64^{b}$ & 0.039 \\
\hline
\end{tabular}

${ }^{\mathrm{a}, \mathrm{b}} \mathrm{On}$ the same row indicate a significant difference $(\mathrm{p}<0.05)$ 
Table 5: Blood hematological on Brahman crossbred cows supplemented with mineral mixture

\begin{tabular}{lllll}
\hline Parameter & CON & MM-A & MM-B & $p$-value \\
\hline Hemoglobin $(\mathrm{g} / \mathrm{dL})$ & $9.47 \pm 0.17$ & $10.60 \pm 0.49$ & $10.32 \pm 0.38$ & 0.113 \\
Hematocrit $(\%)$ & $11.95 \pm 3.96$ & $6.32 \pm 0.87$ & $5.03 \pm 0.69$ & 0.125 \\
Erythrocyte $\left(\times 10^{6} / \mu \mathrm{L}\right)$ & $2.62 \pm 0.82$ & $2.38 \pm 0.17$ & $1.14 \pm 0.12$ & 0.108 \\
Leukocyte $\left(\times 10^{3} / \mu \mathrm{L}\right)$ & $6.67 \pm 0.68$ & $9.13 \pm 0.81$ & $7.03 \pm 1.40$ & 0.213 \\
MCV $(\mathrm{fL})$ & $44.68 \pm 0.85$ & $45.23 \pm 1.05$ & $43.62 \pm 1.03$ & 0.511 \\
MCH $(\mathrm{pg})$ & $57.92 \pm 15.47$ & $82.22 \pm 10.18$ & $96.65 \pm 10.72$ & 0.116 \\
RDW $(\%)$ & $30.63 \pm 1.90$ & $32.05 \pm 1.30$ & $28.98 \pm 1.17$ & 0.371 \\
Granulocyte $\left(\times 10^{3} / \mu \mathrm{L}\right)$ & $2.22 \pm 0.35$ & $2.55 \pm 0.30$ & $2.03 \pm 0.67$ & 0.740 \\
Lymphocyte $\left(\mathrm{x} 10^{3} / \mu \mathrm{L}\right)$ & $3.58 \pm 0.41$ & $5.92 \pm 0.66$ & $4.42 \pm 0.75$ & 0.054 \\
Monocyte $\left(\times 10^{3} / \mu \mathrm{L}\right)$ & $0.88 \pm 0.11$ & $0.68 \pm 0.07$ & $0.55 \pm 0.11$ & 0.086 \\
Granulocyte $(\%)$ & $33.40 \pm 4.08$ & $28.32 \pm 3.17$ & $27.15 \pm 4.05$ & 0.481 \\
Lymphocyte $(\%)$ & $53.28 \pm 4.25$ & $64.43 \pm 2.98$ & $64.95 \pm 4.12$ & 0.082 \\
Monocyte $(\%)$ & $13.32 \pm 1.30^{\mathrm{a}}$ & $7.25 \pm 0.37^{\mathrm{b}}$ & $7.92 \pm 0.37^{\mathrm{b}}$ & 0.000 \\
\hline
\end{tabular}

$\overline{\mathrm{a}, \mathrm{b}}$ On the same row indicate a significant difference $(\mathrm{p}<0.05)$

Table 6: Hormone and pregnancy rate on Brahman Crossbred Cows supplemented with mineral mixture

\begin{tabular}{lllll}
\hline Item & CON & MM-A & MM-B & $p$-value \\
\hline Estrogen $(\mathrm{pg} / \mathrm{mL})$ & $75.08 \pm 11.83$ & $68.12 \pm 14.54$ & $77.19 \pm 19.80$ & 0.914 \\
Progesterone $(\mathrm{ng} / \mathrm{mL})$ & $4.57 \pm 0.73$ & $13.88 \pm 4.65$ & $10.75 \pm 1.60$ & 0.098 \\
Pregnancy rate $(\%)$ & $6.67(2 / 30)$ & $3.33(1 / 30)$ & $20.69(6 / 29)$ & - \\
\hline
\end{tabular}

However, the percentage of monocyte in the treatment MM-B decreased significantly $(\mathrm{p}<0.01)$. For serum minerals, MM-B supplementation significantly increased the serum concentrations of calcium, phosphorus, selenium and iron compared to the CON treatment (Table 4). The result also showed that mineral supplementation had no significant differences in serum progesterone and estrogen $(\mathrm{p}>0.05)$ (Table 6). However, the pregnancy rate in the MM-B treatment $(6 / 29 ; 20.7 \%)$ was higher than $\operatorname{CON}(2 / 30 ; 6.67 \%)$ and MM-A treatment $(1 / 30 ; 3.33 \%)$ (Table 6). The pregnancy rate in Brahman Crossbred cattle using artificial insemination in this study was low in general.

\section{Discussion}

\section{Blood Biochemical, Hematological and Mineral Profile}

Serum glucose concentrations were 54.47; 70.57 and $66.7 \mathrm{mg}$ dl- in the CON, MM-A and MM-B treatments, respectively and there were no differences between mineral supplementation treatments. Similar findings with (Warken et al., 2018) that mineral supplementation on cows diet among 3, 15, 30, 45 and 60 days of treatment did not affect blood glucose. Blood glucose concentration is one of the biochemical indicators of body energy supply (Xuan et al., 2018). Furthermore, mineral mixture supplementation in this study did not affect the serum total protein and serum albumin concentration. Serum protein is part of the collection of amino acids in the body and indicates the nutritional status of livestock (Xuan et al., 2018). Molefe and Mwanza (2020) showed no difference in total blood protein by giving several doses of mineral. Khalil et al. (2019b) mentioned that mineral supplementation on Simmental cows using the different forms (meal and block) did not affect blood protein. Kumar and Dass (2006) also stated that niacin supplementation did not affect serum total protein, glucose, globulin and albumin on female animals fed by wheat straw and concentrate mixture as basal diets. Albumin content in the blood could reflect protein status. Its concentration could be affected by liver function, age, intake of protein and energy and protein dropping during specific illnesses. In addition, the level of several constituents in the blood (total protein, globulin, albumin and $\mathrm{N}$-urea) is a representation of nitrogen adequacy or insufficiency in animal diets (Hammond, 1983).

In the animal body, cholesterol was synthesized from fatty acids. The blood cholesterol level indicates the body's lipid metabolism. In this study, supplementation of mineral mixture did not affect the serum cholesterol and serum triglyceride concentrations. A similar trend by Satapathy et al. (2016) showed no significant dissimilarity in serum cholesterol and serum triglyceride concentrations on 0 and 60 days after mineral supplementation. The serum cholesterol and serum triglycerides concentrations on the 60-day were 108.45 and $80.84 \mathrm{mg}$ dl-, respectively. However, Oliveira et al. (2014) reported an increase in hypocholesterolemic status after 60 days of mineral mixture supplementation. Mineral mixture supplementation did not generally affect blood hematology in Brahman Crossbred cattle, including hemoglobin, erythrocyte, leukocyte, MCV, $\mathrm{MCH}$ and RDW. The same trend was reported by Khalil et al. (2019b) that mineral supplementation in Simmental cattle did not affect hemoglobin, hematocrit, MCHC, red blood cells but increased white blood cells. Overall, the blood hematology in this research was in the normal range, as showed by Weiss and Wardrop (2011). 
The amount of granulocyte, lymphocyte and monocyte cells was not affected by treatments. However, mineral supplementation of MM-B and MM-A significantly decreased $(p<0.01)$ the percentage of monocytes in blood hematology. The monocyte percentage in the CON group was $13.31 \%$ but lower in the MM-A and MM-B groups, 7.25 and $7.92 \%$, respectively. Whereas Roland et al. (2014) stated that the normal range of monocyte presentation was 0 until $8 \%$ of total white blood, so the monocyte percentage in the $\mathrm{CON}$ group was higher than the normal range. Monocyte count tends to increase also in the CON group $(p=0.086)$. It might be suspected that during the blood collection process, the cattle had experienced stress, increasing monocytes. Van Engen et al. (2014) stated that monocyte profiles followed a similar stress response. So, animals had increased blood monocyte numbers. Monocytosis had been seen during intense stress and in the recuperating period of acute and persistent infections (Latimer, 2011). However, some studies mentioned that mineral supplementation reduced stress activity; Gao et al. (2018) explained that zinc on high concentration decreased the viability of monocyte cell line. Supplementation of zinc also reduced inflammatory cytokines and oxidative stress (Prasad, 2014). Ahrens et al. (2008) found that selenium supplementation induced metalloproteinase-dependent L-selectin, resulting in decreased monocyte rolling and adhesion under shear stress conditions. Trace mineral supplementation (e.g., zinc, selenium and copper) improves the immune system and production of superoxide (Batistel et al., 2017).

Mineral supplementation had a significant effect on blood mineral levels. Serum calcium and phosphor levels in the MM-B treatment were higher than CON treatment. Sahoo et al. (2017) reported similar findings, increasing serum mineral in cattle supplemented with the mineral combination in feed. Venjakob et al. (2017) showed that increased blood calcium concentration was linear with calcium levels given to animals. It might be vitamin D, which acts as 1,25-dihydroxycholecalciferol, stimulates calcium channels and facilitates calcium absorption in the intestinal mucosa. Inorganic phosphorus plays an essential role in accelerating ovulation and fertilization in cows (Wu and Satter, 2000). Phosphorus is often associated with energy metabolism, which is necessary for fertilization and embryo growth. Therefore, phosphorus deficiency can lead to premature embryonic death leading to repeated breeding or anestrous conditions (Ali et al., 2014).

Serum selenium and iron levels in the MM-B treatment were higher than those in CON treatment. MM-B has a higher concentration of selenium and iron, thus increasing absorption in the body. Hall et al. (2014) reported that cows were given super nutritional selenium-yeast supplementation during 8-weeks before calving had higher blood selenium concentrations at $48 \mathrm{~h}$ and 14 days of lactation. Chelated mineral mixture supplementation in buffaloes could increase serum iron 45 and 90 days after supplementation (Joshi et al., 2019).

\section{Pregnancy Rate}

The pregnancy rate in the MM-B treatment $(6 / 29 ; 20.7 \%)$ was higher than $\mathrm{CON}(2 / 30 ; 6.67 \%)$ and MM-A treatment $(1 / 30 ; 3.33 \%)$. However, the pregnancy rate in Brahman Crossbred cattle in this study was low in general. It might be caused by the low level of nutrients consumed by animals; it could be seen in Table 3 that the feed consumed has a relatively low balance of energy and protein. The dry matter intake of all treatment groups was around $17.46 \mathrm{~kg} / \mathrm{day}$. The results were following the NRC (2000), in which the dry matter intake for reproductive cattle was above $3 \%$ of Body Weight (BW). However, the TDN and protein intake in this research was still far below the range of Kamada (2017) in reproductive cattle, which was around $17.23 \mathrm{~kg} /$ day for TDN intake $(2.51 \%$ of $\mathrm{BW})$ and $4.03 \mathrm{~kg} /$ day for crude protein intake $(0.59 \%$ of BW), while this finding for the TDN intake was only $7.77 \mathrm{~kg} /$ day $(1.97 \%$ of BW) and $1.11 \mathrm{~kg} /$ day for crude protein intake $(0.28 \%$ of BW). Spicer et al. (1993) stated that the reproductive performance of cows could be affected by protein and energy intake. Kang et al. (2020) suggested feeding concentrate and hay until $120 \%$ of cows' nutrient requirement had many transferable and high-quality embryos.

The results obtained were similar to Ervandi et al. (2020) that Brahman Crossbred cows fed low-quality feed will produce a low pregnancy rate. Haque et al. (2015) also suggested that the variety of feed given to breeding cows (fresh forage, straw and concentrate mixture) increased reproductive hormone, resulting in a better pregnancy percentage. In this study, early detection of pregnancy was assumed to be using 21-NRR. The results showed more excellent results (CON: 60.00\%, MM-A: $66.67 \%$, MM-B: $72.41 \%$ ) than confirmation of pregnancy using rectal palpation on the $90^{\text {th }}$-day post-AI. We also suspected that low nutrient intake could lead to premature embryonic death. Unfortunately, the direct embryo examination was not carried out. Nutrient deficiency can reduce fertility (Boland and Lonergan, 2003).

Regarding the timing of artificial insemination, Ervandi et al. (2020) also performed artificial insemination at almost the same hour (8-10 $\mathrm{h}$ after estrous detection); they showed that Brahman cows had a few numbers of pregnancy rate $(27.5 \%, 11 / 40)$. In contrast, Sutiyono et al. (2018) showed that the others breed cattle, Ongole Grade and Simmental-Ongole Crossbred, had a higher pregnancy rate (70.59 and 50.00\%). In addition, fertility rates in beef cattle pasture-grazing with natural mating systems were usually very high. Under normal conditions, $90 \%$ of ovulated ovarium were successfully fertilized. However, this condition did not occur in crossbred cattle using artificial insemination with varying failure rates, according to the composition of the genotype (Diwyanto and Inounu, 
2009). Ervandi et al. (2020) also examined the pregnancy rate using the ultrasonography observation of Brahman crossbred cows. The results showed that those crossbred cows had several ovarian abnormalities. Many factors should be evaluated, including the high cases of ovarian hypo-function in productive cattle due to crossbreeding (Dibia et al., 2015).

However, among the various factors affecting the percentage of pregnancy in Brahman Cross cattle by artificial insemination, the MM-B treatment showed a better response to pregnancy percentage than other treatments. Numerous investigations linking mineral supplementation with successful pregnancy are related to increasing progesterone in the blood. Although in this study, serum progesterone levels did not show a significant difference. That was possible with a different blood sampling process, where sampling for progesterone testing had been done before artificial insemination. As research by Khalil et al. (2019a), who took blood samples for progesterone testing at 16 weeks in female goats, had a linear increase in serum progesterone levels with the addition of mixed minerals in the feed. However, Khalil et al. (2019b) also reported that mineral supplementation did not affect serum progesterone levels of female cattle taken at 14 weeks. Ganie et al. (2014) showed that selenium supplementation did not significantly differ initially and during estrous but increased estrogen and progesterone hormones at the end of treatment.

Behera et al. (2012) found linear results with mineral supplementation with an increase in pregnancy rates. In cows, lack of standard copper, manganese and zinc lead to postponed estrous, unusual estrous, decreased conception, juvenile ovaries, infertility and embryonic decease (Yasothai, 2014). Supplementation of certain mineral mixtures of calcium, phosphor, zinc, manganese improved growth performance, estrous quality and pregnancy rate in crossbred cows (Mohapatra et al., 2012; Sahoo et al., 2016). Zinc assumes a fundamental part in the sexual turn of events and is concerned with developing ovarian follicles, which might source the progesterone hormone (Yatoo et al., 2013). Copper is an essential part of superoxidase dismutase enzyme activity, controlling luteal cells to produce progesterone hormone (Sales et al., 2011). Ahmed et al. (2010) stated that copper deficiency showed low ovarian activity correlated with oxidative stress. Iron plays an essential function in embryo development; as a result, Gao et al. (2007), oocyte maturation was not affected by iron supplementation, but it improved the development rate to the 8-cell, morula and blastocyst phases. Sales et al. (2011) also reported that the adequacy of some trace minerals (copper, zinc, manganese and selenium) reduced early embryonic death, resulting in an increased pregnancy rate on crossbred cows.

\section{Conclusion}

The supplementation of mineral mixtures affected the mineral serum concentration and did not affect the blood biochemical and hematological profiles. The supplementation of mineral mixture B-formulation (high mineral concentration) increased the pregnancy rate on Brahman Crossbred cows.

\section{Acknowledgment}

This research was funded by Prioritas Riset Nasional (PRN), Indonesia Government, under grant number 50/E1/PRN/2020. We should also like to thank PT. Widodo Makmur Perkasa for providing all facilities in this study.

\section{Author's Contributions}

Mohammad Sofi'ul Anam and Ali Agus: Contributed to the designing, conducting the experiment and preparing the first draft.

Lies Mira Yusiati, Chusnul Hanim and Sigit Bintara: Conducted the laboratory analysis and interpreted the obtained data.

Andriyani Astuti and Muhsin Al Anas: Contributed to the correction of the manuscript and data interpretation.

\section{Ethics}

This article was original, no ethical issues were involved and it contained unpublished material. The corresponding author ensured that the final manuscript had been read and approved by all authors.

\section{References}

Agus, A., \& Widi, T. S. M. (2018). Current situation and future prospects for beef cattle production in Indonesia-A review. Asian-Australasian Journal of Animal Sciences, 31(7), 976. doi.org/10.5713/ajas.18.0233

Ahmed, W. M., El-Khadrawy, H. H., Hanafi, E. M., Ali, A. H., \& Shalaby, S. A. (2010). Clinical perspective of repeat breeding syndrome in buffaloes. Journal of American Science, 6(11). http://www.jofamericanscience.org/journals/amsci/a m0611/98_4107am0611_661_666.pdf

Ahola, J. K., Baker, D. S., Burns, P. D., Mortimer, R. G., Enns, R. M., Whittier, J. C., ... \& Engle, T. E. (2004). Effect of copper, zinc and manganese supplementation and source on reproduction, mineral status and performance in grazing beef cattle over a two-year period. Journal of Animal Science, 82(8), 2375-2383. doi.org/10.2527/2004.8282375x 
Ahrens, I., Ellwanger, C., Smith, B. K., Bassler, N., Chen, Y. C., Neudorfer, I., ... \& Peter, K. (2008). Selenium supplementation induces metalloproteinase-dependent L-selectin shedding from monocytes. Journal of Leukocyte Biology, 83(6), 1388-1395. doi.org/10.1189/jlb.0707497

Ahuja, A., \& Parmar, D. (2017). Role of minerals in reproductive health of dairy cattle: a review. Int. J. Livest. Res, 7(10), 16-26. doi.org/10.5455/ijlr.20170806042724

Ali, F., Lodhi, L. A., Hussain, R., \& Sufyan, M. (2014). Oxidative status and some serum macro minerals during estrus, anestrous and repeat breeding in Cholistani cattle. Pak Vet J, 34(4), 532-534. http://www.pvj.com.pk/abstract/34_4/13-144.htm

AOAC. (2005). Official Metods of Analysis (18th ed.). Association of Official Analytical Chemists.

Batistel, F., Osorio, J. S., Tariq, M. R., Li, C., Caputo, J., Socha, M. T., \& Loor, J. J. (2017). Peripheral leukocyte and endometrium molecular biomarkers of inflammation and oxidative stress are altered in peripartal dairy cows supplemented with $\mathrm{Zn}, \mathrm{Mn}$ and $\mathrm{Cu}$ from amino acid complexes and $\mathrm{Co}$ from $\mathrm{Co}$ glucoheptonate. Journal of Animal Science and Biotechnology, 8(1), 1-12. doi.org/10.1186/s40104-017-0163-7

Behera, P. C., Das, M., Tripathy, D. P., Panigrahi, B., \& Panda, N. (2012). Mineral supplementation and its relevance in improving conception rate in anestrus and repeat breeding heifers. Intas Polivet, 13(1), 17-21. https://www.indianjournals.com/ijor.aspx?target=ijo r:ipo\&volume $=13 \&$ issue $=1 \&$ article $=004$

Bindari, Y. R., Shrestha, S., Shrestha, N., \& Gaire, T. N. (2013). Effects of nutrition on reproduction-A review. Adv. Appl. Sci. Res, 4(1), 421-429. https://www.imedpub.com/abstract/effects-ofnutrition-on-reproduction-a-review-14803.html

Boland, M. P., \& Lonergan, P. (2003). Effects of nutrition on fertility in dairy cows nutrition and gonadotrophin secretion. Advances in Dairy Technology, 15(18), 19-33. https://wcds.ualberta.ca/

Caixeta, L. S., Ospina, P. A., Capel, M. B., \& Nydam, D. V. (2017). Association between subclinical hypocalcemia in the first 3 days of lactation and reproductive performance of dairy cows. Theriogenology, 94, 1-7. doi.org/10.1016/j.theriogenology.2017.01.039

Dibia, I. N., Dartini, N. L., \& Arsani, N. M. (2015). Cattle reproductive disorders in Lombok Island West Nusa Tenggara Province. Buletin Veteriner, XXVII (87). http://bbvdps.ditjenpkh.pertanian.go.id/

Diwyanto, K., \& Inounu, I. (2009). The impact of crossbreeding in the artificial insemination program on reproductive performance of beef cattle. Indonesian Bulletin of Animal and Veterinary Sciences, 19(2), 93-102.

doi.org/10.14334/wartazoa.v19i2.926
Ervandi, M., Ihsan, M. N., Wahjuningsih, S., \& Susilawati, T. (2020). Pregnancy rate and reproductive disorders examination of inseminated brahman cross cows by rectal palpation and ultrasonography. American Journal of Animal and Veterinary Sciences, 15(1), 0-7. doi.org/10.3844/ajavsp.2020.73.80

Ganie, A. A., Baghel, R. P. S., Mudgal, V., Aarif, O., \& Sheikh, G. G. (2014). Effect of selenium supplementation on reproductive performance and hormonal profile in buffalo heifers. Indian Journal of Animal Research, 48(1), 27-30. doi.org/10.5958/j.0976-0555.48.1.006

Gao, G., Yi, J., Zhang, M., Xiong, J., Geng, L., Mu, C., \& Yang, L. (2007). Effects of iron and copper in culture medium on bovine oocyte maturation, preimplantation embryo development and apoptosis of blastocysts in vitro. Journal of Reproduction and Development, 0704050071-0704050071. doi.org/10.1262/jrd.18109

Gao, H., Dai, W., Zhao, L., Min, J., \& Wang, F. (2018). The role of zinc and zinc homeostasis in macrophage function. Journal of immunology research, 2018. doi.org/10.1155/2018/6872621

Hall, J. A., Bobe, G., Vorachek, W. R., Kasper, K., Traber, M. G., Mosher, W. D., ... \& Gamroth, M. (2014). Effect of supranutritional organic selenium supplementation on postpartum blood micronutrients, antioxidants, metabolites and inflammation biomarkers in selenium-replete dairy cows. Biological Trace Element Research, 161(3), 272-287. doi.org/10.1007/s12011-014-0107-4

Hammond, A. C. (1983). The use of blood urea nitrogen concentration as an indicator of protein status in cattle. The Bovine Practitioner, 114-118. doi.org/https://doi.org/10.21423/bovinevol1983no18p114-118

Haque, M. N., Gofur, M. R., Asaduzzaman, K. M., \& Bhuiyan, M. M. U. (2015). Factors limiting the pregnancy rates in artificially inseminated cows in Bangladesh. Int J Dairy Sci, 10(10), 278-87. doi.org/10.3923/ijds.2015.278.287

Joshi, P. M., Patel, D. C., \& Patel, P. D. (2019). Effect of chelated mineral mixture on blood biochemistry, hormone and mineral status in repeat breeder buffaloes in tribal areas of Dahod district in Gujarat, India. The Indian Journal of Veterinary Sciences and Biotechnology, 15(01), 40-44. doi.org/10.21887/ijvsbt.15.1.9

Kamada, H. (2017). Effects of selenium-rich yeast supplementation on the plasma progesterone levels of postpartum dairy cows. Asian-Australasian Journal of Animal Sciences, 30(3), 347. doi.org/10.5713/ajas.16.0372 
Kang, S. S., Kim, U. H., Han, M. H., \& Cho, S. R. (2020). Nutrient requirements in Hanwoo cows with artificial insemination: effects on blood metabolites and embryo recovery rate. Journal of Animal Science and Technology, 62(4), 449. doi.org/10.5187/JAST.2020.62.4.449

Khalil, Bachtiar, A., \& Evitayani, E. (2019a). Reproductive performance of Female Kacang Goats supplemented by mineral under a tethering feeding system. Tropical Animal Science Journal, 42(3), 215223. doi.org/10.5398/tasj.2019.42.3.215

Khalil, Bachtiar, A., \& Udin, Z. (2019b). Effects of mineral supplementation on reproductive efficiency of Simmental heifers. Asian Journal of Agriculture and Biology, 7(3), 396-403.

https://www.asianjab.com/wpcontent/uploads/20191 0/9.-AJAB-2019-01-03_Okay.pdf

Kumar, R., \& Dass, R. S. (2006). Effect of niacin supplementation on growth, nutrient utilization and blood biochemical profile in male buffalo calves. AsianAustralasian Journal of Animal Sciences, 19(10), 1422-1428. doi.org/10.5713/ajas.2006.1422

Kumar, S., Pandey, A. K., AbdulRazzaque, W. A., \& Dwivedi, D. K. (2011). Importance of micro minerals in reproductive performance of livestock. Veterinary World, 4(5), 230. doi.org/10.5455/vetworld.2011.230-233

Latimer, K. S. (Ed.). (2011). Duncan and Prasse's veterinary laboratory medicine: clinical pathology. John Wiley \& Sons. ISBN-10: 0813820146.

Leigh, O. O., Mustapha, L., Linda, A. C., \& Ibiam, A. E. (2019). Timed Artificial Insemination: Pregnancy Rates in Sokoto Gudali Cattle Treated with Prostaglandin F2 Alpha at a Private Dairy Farm in Nigeria. Animal Production, 20(1), 1-6. doi.org/10.20884/1.jap.2018.20.1.636

Martinez, N., Sinedino, L. D. P., Bisinotto, R. S., Daetz, R., Risco, C. A., Galvão, K. N., ... \& Santos, J. E. P. (2016). Effects of oral calcium supplementation on productive and reproductive performance in Holstein cows. Journal of dairy science, 99(10), 8417-8430. doi.org/10.3168/jds.2015-10529

Mohapatra, P., Swain, R. K., Mishra, S. K., Sahoo, G., \& Rout, K. K. (2012). Effect of supplementation of area specific mineral mixture on reproductive performance of the cows. Indian Journal of Animal Sciences, 82(12), 1558-1563.

http://epubs.icar.org.in/ejournal/index.php/IJAnS/ article/view/25694/11883

Mokolopi, B. G. (2019). Phosphorus, calcium and magnesium contents of pasture and their effect on body condition scores and body mass of communal cattle depending on natural pasture of Mogosane Village, of the North-West Province, South Africa. Tropical Animal Health and Production, 51(7), 2067-2071. doi.org/10.1007/s11250-019-01908-Z
Molefe, K., \& Mwanza, M. (2020). Effects of mineral supplementation on reproductive performance of pregnant cross-breed Bonsmara cows: An experimental study. Reproduction in Domestic Animals, 55(3), 301-308. doi.org/10.1111/rda.13618

Niaz, F., Sethy, K., Swain, R. K., Behera, K., Mishra, S. K., Karna, D. K., \& Mishra, C. (2017). Combined effect of concentrate and area specific mineral mixture supplementation on the performance of Ganjam goat in its native tract. Pharma Innov, 6, 320-323. www.thepharmajournal.com

NRC. (2000). Nutrient Requirements of Beef Cattle (7th ed.). The National Academic Press. doi.org/10.17226/9791

Oliveira, R. R., Rates, D. M., Pugliesi, G., Ker, P. G., Arruda, R. P., Moraes, E. A., \& Carvalho, G. R.

(2014). Use of cholesterol - loaded cyclodextrin in donkey semen cryopreservation improves sperm viability but results in low fertility in mares. Reproduction in Domestic Animals, 49(5), 845-850. doi.org/10.1111/rda.12379

Patterson, H. H., Adams, D. C., Klopfenstein, T. J., Clark, R. T., \& Teichert, B. (2003). Supplementation to meet metabolizable protein requirements of primiparous beef heifers: II. Pregnancy and economics. Journal of Animal Science, 81(3), 563-570. doi.org/10.2527/2003.813563x

Prasad, A. S. (2014). Zinc is an antioxidant and anti-inflammatory agent: its role in human health. Frontiers in nutrition, 1, 14. doi.org/10.3389/fnut.2014.00014

Roland, L., Drillich, M., \& Iwersen, M. (2014). Hematology as a diagnostic tool in bovine medicine. Journal of Veterinary Diagnostic Investigation, 26(5), 592-598. doi.org/10.1177/1040638714546490

Sahoo, J. K., Das, S. K., Sethy, K., Mishra, S. K., Swain, R. K., Mishra, P. C., \& Satapathy, D. (2016). Effect of supplementation of mineral mixture and bypass fat on performance of crossbred cattle. Journal of Animal Research, 6(4), 611-618. doi.org/10.5958/2277-940x.2016.00071.1

Sahoo, J., Das, S., Sethy, K., Mishra, S., Swain, R., \& Mishra, P. (2017). Effect of feeding area specific mineral mixture on haemato biochemical, serum minerals and ovarian status of reproductive disordered crossbred cattle in Jatani block of Odisha. International Journal of Livestock Research, 7(5), 98-104. doi.org/10.5455/ijlr.20170324032412

Saili, T. (2017). Pregnancy rate of Bali Cows following artificial insemination using chilled sexed sperm under intensive management in tropical area. In International Seminar on Tropical Animal Production (ISTAP) (pp. 738-742).

https://journal.ugm.ac.id/istapproceeding/article/view/2 9918 
Sales, J. N. S., Pereira, R. V. V., Bicalho, R. C., \& Baruselli, P. S. (2011). Effect of injectable copper, selenium, zinc and manganese on the pregnancy rate of crossbred heifers (Bos indicus $\times$ Bos taurus) synchronized for timed embryo transfer. Livestock Science, 142(1-3), 59-62. doi.org/10.1016/j.livsci.2011.06.014

Satapathy, D., Mishra, S. K., Swain, R. K., Sethy, K., \& Sahoo, G. R. (2016). Effect of supplementation of area specific mineral mixture on performance of crossbred cows with reproductive disorders in Kakatpur Block. Indian Journal of Animal Nutrition, 33(3), 279-284. doi.org/10.5958/2231-6744.2016.00049.9

Spicer, L. J., Vernon, R. K., Tucker, W. B., Wettemann, R. P., Hogue, J. F., \& Adams, G. D. (1993). Effects of inert fat on energy balance, plasma concentrations of hormones and reproduction in dairy cows. Journal of Dairy Science, 76(9), 2664-2673. doi.org/10.3168/jds.S0022-0302(93)77602-X

Susilowati, S., Sardjito, T., Mustofa, I., Widodo, O. S., \& Kurnijasanti, R. (2021). Effect of green tea extract in extender of Simmental bull semen on pregnancy rate of recipients. Animal Bioscience, 34(2), 198. doi.org/10.5713/ajas.20.0025

Sutiyono, S., Samsudewa, D., \& Suryawijaya, A. (2018). Estrus and pregnancy rate of SimmentalO'ngole crossbred and Ongole grade heifer after being synchronized and inseminated. J. Indones. Trop. Anim. Agric, 43, 438-444. doi.org/10.14710/jitaa.43.4.438-444

Talukdar, D. J., Talukdar, P., \& Ahmed, K. (2016). Minerals and its impact on fertility of livestock: A review. Agricultural Reviews, 37(4), 333-337. doi.org/10.18805/ag.v37i4.6464

Van Engen, N. K., Stock, M. L., Engelken, T., Vann, R. C., Wulf, L. W., Karriker, L. A., ... \& Coetzee, J. F. (2014). Impact of oral meloxicam on circulating physiological biomarkers of stress and inflammation in beef steers after long-distance transportation. Journal of Animal Science, 92(2), 498-510. doi.org/10.2527/jas.2013-6857
Venjakob, P. L., Borchardt, S., \& Heuwieser, W. (2017). Hypocalcemia-Cow-level prevalence and preventive strategies in German dairy herds. Journal of Dairy Science, 100(11), 9258-9266. doi.org/10.3168/jds.2016-12494

Warken, A. C., Lopes, L. S., Bottari, N. B., Glombowsky, P., Galli, G. M., Morsch, V. M., ... \& Silva, A. S. (2018). Mineral supplementation stimulates the immune system and antioxidant responses of dairy cows and reduces somatic cell counts in milk. Anais da Academia Brasileira de Ciências, 90, 1649-1658. doi.org/10.1590/0001-3765201820170524

Weiss, D. J., \& Wardrop, K. J. (Eds.). (2011). Schalm's veterinary hematology. John Wiley \& Sons. ISBN-10: 047096183X.

Wu, Z., \& Satter, L. D. (2000). Milk production and reproductive performance of dairy cows fed two concentrations of phosphorus for two years. Journal of Dairy Science, 83(5), 1052-1063. doi.org/10.3168/jds.S0022-0302(00)74969-1

Xuan, N. H., Loc, H. T., \& Ngu, N. T. (2018). Blood biochemical profiles of Brahman crossbred cattle supplemented with different protein and energy sources. Veterinary World, 11(7), 1021. doi.org/10.14202/vetworld.2018.1021-1024

Yasothai, R. (2014). Importance of minerals on reproduction in dairy cattle. International Journal of Science, Environment and Technology, 3(6), 2051-2057. https://www.ijset.net/journal/446.pdf

Yatoo, M. I., Saxena, A., Deepa, P. M., Habeab, B. P., Devi, S., Jatav, R. S., \& Dimri, U. (2013). Role of trace elements in animals: A review. Veterinary World, 6(12), 963-967. doi.org/10.14202/vetworld.2013.963-967

Yatoo, M., Parray, O., Ashraf, T., Ashraf, S., Nisar, M., \& Taifah, S. (2018). Longitudinal study on evaluation of serum micromineral and hormone interrelation in cattle. Journal of Pharmacognosy and Phytochemistry, 7(2), 1201-1203.

http://www.phytojournal.com/archives/2018/vol7iss ue2/PartQ/7-2-19-539.pdf 